\title{
Research on Spoken English Learning Strategies Between English Major and Non-English Major Learners
}

\author{
ZHENG Ling, HAN Bing \\ Changchun University, Changchun, China
}

\begin{abstract}
The spoken English learning of non-English major learners is quite different from the English majors, especially the learning ways. Therefore, it requires that the learners make changes and choices of the learing means and ways according to their specific characteristics and conditions, so as to enhance the efficiency of the overall learning of English. This paper makes s concrete analysis about the necissesity of spoken learning of English major and non-English major learners, discusses the widespread problems on spoken English learning of English major and non-English major learners, and proposes some practical strategies that are applied in the process of spoken English learing.

Keywords: English major, non-English major, oral language, learning strategy
\end{abstract}

\section{Introduction}

At present, the colleges are overwhelmed by the reform of English teaching. Then many colleges and universities start to open oral classes for students, so as to satisfy the requirements of the changing times. The setting up of spoken English class for English and non-English major learners conforms to the modern English teaching philosophy. However, for English and non-English major learners, it is a big challenge to follow the changes. They should motivate their learning concepts and methods, using the specific learning strategies reasonably.

\section{Analysis on Necessity of Spoken English Learning of English Major and Non-English Major Learners}

Influenced by the highly development of our countries' economy, technology, culture, and education, the traditional college English curriculum is confronted with more and more challenges. Under the condition of international communication becoming more and more frequent, the exam-oriented education specified by knowledge is also becoming more awkward of cultivating talented students that are needed by the technologic, informational, and international society. Therefore, the urgent task of our countries' education is cultivating a large number of comprehensive talented students with professional skills and English communication ability by changing the exam-oriented education into quality education and changing the education mode from knowledge

ZHENG Ling, lecturer, master, Foreign Languages College, Changchun University. HAN Bing, lecturer, master, Foreign Languages College, Changchun University. 
imparting to ability cultivating. Besides, reforming the teaching of collage students' spoken language is one of the changes referred above. It is for this reason that many colleges and universities have made a lot of researches on the oral English learning strategies of English majors and non-English majors based on the actual spoken English teaching conditions in our country.

Under the premise that the current college English intensive reading classes are not reduced, "college oral English course" are set for English and non-English majors, in order to enable the students to accept the training of spoken English systematically which does a great help in enhancing students' communicative competence both in work and in lives.

\section{The Widespread Problems on Spoken English Learning of English Major and Non-English Major Learners}

\section{Oral Practice Time Is Limited}

For the majority of the students, the class is the only way to learn spoken English for English and non-English major learners, intensive reading, spoken and listening time is extremely limited. Some students even do not listen carefully in class. The input and output of English is very poor. The ideal way of learning a second language is to learn and understand the target language, with the comprehensible language input getting larger and more complex. The learner will obtain the ability of use language to express their own ideas. Therefore, limited English speaking and listening time makes it difficult for students to obtain the spoken English ability and psychological preparation for expressing their ideas in English.

\section{Lack of Confidence in Spoken English Learning}

Most students have awareness of the importance of spoken English learning, but they feel daunted by the spoken English task ahead. Each student's wish is to be able to speak fluent English, but when achieving the aspirations, they exhibit the self-confidence. One important reason is that they have never made remarkable achievements in spoken English learning, which is related to the characteristics of spoken English learning and the understanding of spoken English learning. English learning, especially the improvement of spoken English ability, is a relatively long process, which determines its progress is not dominant. And the characteristics of students do not have enough patience; in their hearts, the improvement of spoken language is like a flower that will never bear fruit. The confidence of spoken English learning of the students will be completely lost with age, which gradually reduces the initiative and innovation of spoken English learning.

\section{The Application Ability of Spoken English Is Poor}

There are little differences between the English majorand non-English major learners in vocabulary and grammar. The students' English vocabulary has been accumulated to a certain degree, but in oral expression, some students cannot flexibly apply the spoken vocabulary that has been already mastered. They still think in oral expression, their vocabulary is not enough. It shows that students reading vocabulary is not equivalent to oral vocabulary that can be flexibly applied in oral expression. And the in the pronunciation, there are also various degree of problem in English major and non-English major learners: Their pronunciation and intonation are not enough standard; the consistency and fluency of spoken English remain to be improved. 


\section{Research on Spoken English Learning Strategies of English Major and Non-English Major Learners}

\section{The Spoken English Learning Strategies of English Major Learners}

Rich the second classroom activities, effectively expand the spoken English class. English major learners basically arrange a spoken English class once a week; students generally reflect that the spoken English class teaching time cannot satisfy the desire of improving spoken English. Teacher should carry out the second classroom activities, such as English corner, English lectures, English speech competition, English knowledge contest, English song competition, English movie appreciation, etc., effectively develop language environment to improve students spoken English, to realize the combination of spoken English class teaching and second class activities, and to promote and influence each other.

Supply the cultural knowledge to students. Learning English is not only to master the pronunciation and vocabulary, but also to have a full understanding the cultural background and customs of the communicative object. Relevant research scholars have pointed out that "language and culture are closely intertwined" (ZHANG, 2013, pp. 87-89), Language is the product or result of the whole culture and it is also the medium of the formation and communication of other elements of culture. Through culture, learners' language learning results will be better. The appropriateness of language is inseparable from social and cultural knowledge. English major learners' spoken English training is mainly in order to cultivate their ability of cross-cultural communication, to have an eye on all aspects of oral knowledge and content, to be able to master the spoken language knowledge, to think and react like native language learners, and to have a strong adaptability and communication skills.

Improve the ability of using spoken English to express independent views and ideas. English major learners in the process of learning spoken English should in the more real communication context to improve spoken English. Spoken English content should have a considerable difficulty; spoken English exercise can be a social hot issue, such as political and economic reform in our country, the tension of global energy, the international fight against terrorism, etc.; it can be also a more controversial problem. The purpose of implement spoken English activities is to stimulate students' interest and promote them to think positively. In terms of spoken English learning forms, students can take more challenging activities such as debates. The spoken English ability, cultural quality, and oral communication skills of students can be tested comprehensively, along with the increase of such activities improved step by step. In addition, in order to achieve the desired effect of oral English learning, students should consciously cultivate the organization ability, social language ability, and strategy ability.

\section{The Spoken English Learning Strategies of Non-English Major Learners}

Adjust attitude, enhance the confidence of learning spoken English. First of all, the non-English major learners should have the confidence to improve their spoken English ability. On the one hand, students must build up the confidence through various means, for example, often recall their successful English speech or communication context, etc.; on the other hand, teachers should help students set up their confidence, improve students English ability both in the classroom and usual activities. Teachers' word and deeds, even a casual evaluation, will produce a very big effect on students, and the higher the status of the teacher in students mind, the greater the effect. Therefore, the teacher should make a full use of the psychological effects, to help 
students set up the confidence of spoken English learning. Secondly, students should overcome the fear of speaking English, without feeling shame even if it is not good. The students are learning, but not in the show. In fact, when a person join in the English corner with unfluent spoken English, more people admire his courage and confidence. So, students must overcome this psychological barrier and correct their attitude, in order to improve their spoken language.

Make full use of spoken English teaching in class. For non-English major learners, the main way to learn spoken English is classroom teaching; this requires learners should make an efficient use of class time, improve concentration, interact positively with teachers; guaranteeing in the classroom can master basic oral English and oral English skills.

Many studies about spoken English class teaching have shown that: When students acquire comprehensible input from the spoken English class, the efficiency of classroom teaching is higher. The comprehensible input here means that students can understand what the teacher says. Therefore, in order to realize the maximization of the effect of spoken English classroom teaching, it requires that students should actively participate in the spoken English class learning process, strive for more comprehensible input, and make full use of spoken English class teaching to improve their spoken English ability.

Create a spoken English learning environment after class, insist on training spoken English. Spoken English is in accordance with the rules of grammar, social experience, and under the control of the emotion, reasonable organize the pronunciation and vocabulary together, eventually produce meaningful language ability. Students are the main body of learning English; they can create all kinds of English environment for themselves, such as finding the right friend chat in English, actively communicating with teachers in English in spare time, logging online English chat rooms, etc; next, students should make full use of the opportunities to hear English, they can also join in English corner, in the English circumstances practicing their spoken ability, exercising English listening at the same time. Students may use English language environment, seize every opportunity to practice spoken English, to inspire the enthusiasm of spoken English learning.

\section{Conclusion}

As one kind of language, English is basically for communication. And the level of student's spoken language can directly reflect his or her basic knowledge of English and the application ability of language. The requirements of teaching college English curriculum makes an emphasis that the goal of collage English teaching is to develop the comprehensive ability of students' applying English, especially the skill of speaking and listening. English major and non-English major learners must correctly realize their own deficiencies, improve the attention on the spoken English learning combined with their own actual situation, make full use and create the spoken English learning environment, flexibly apply spoken English learning strategies, gradually improve the spoken English ability, and promote the comprehensive development of themselves.

\section{References}

JIAO, L. X. (2013). Survey of non-English major learners' use of spoken English learning strategies. Beijing University of Posts and Telecommunications, 14(9), 66-68.

LI, H. (2010). A study on the current situation of spoken English and corresponding strategies of higher vocational college non-English majors. Journal of Liaoning Provincial College of Communications, 22(5), 61. 
LIN, D. M. (2012). A study of the learning strategies used by Uyghur English major undergraduates in learning English. Journal of Xinjiang University, 57(14), 80-82.

ZHANG, C. G. (2013). An empirical study of spoken English abilities of higher vocational students. Journal of Hunan Industry Polytechnic, 32(6), 87-89.

ZHANG, Q. Y. (2009). A comparative study of English reading strategies used by non-English major students. Journal of Anhui Agricultural University, 28(12), 62-63.

ZHONG, X. F. (2011). The implementation of the strategies on open education spoken English teaching of cooperative learning. Journal of Hubei Radio \& Television University, 17(3), 172-174. 